\title{
Brief adrenomedullin inhalation leads to sustained reduction of pulmonary artery pressure
}

\author{
K. von der Hardt ${ }^{\uparrow}$, M.A. Kandler ${ }^{\top *}$, M. Chada*, A. Cubra*, E. Schoof*, K. Amann\# ${ }^{\#}$ W. Rascher*, \\ J. Dötsch*
}

Brief adrenomedullin inhalation leads to sustained reduction of pulmonary artery pressure. K. von der Hardt, M.A. Kandler, M. Chada, A. Cubra, E. Schoof, K. Amann, W. Rascher, J.Dötsch. (C) ERS Journals Ltd 2004.

ABSTRACT: The effect of aerosolised adrenomedullin (ADM), a potent vasodilator peptide, on pulmonary artery pressure was studied for $24 \mathrm{~h}$ in a surfactant-depleted piglet model.

Animals received either aerosolised ADM $\left(50 \mathrm{ng} \cdot \mathrm{kg}^{-1} \cdot \mathrm{min}^{-1}\right.$, ADM, $\left.\mathrm{n}=6\right)$, or aerosolised normal saline solution (control, $n=6$ ). Aerosol therapy was performed for a $2 \mathrm{~h}$ treatment period followed by a $22 \mathrm{~h}$ observation period. Ventilator settings were adapted to keep arterial oxygen tension and carbon dioxide arterial tension between $13.3-14.6 \mathrm{kPa}$ and $4.9-5.7 \mathrm{kPa}$, respectively.

Aerosolised ADM reduced mean pulmonary artery pressure (MPAP) compared with the control group (end-point median $24 \mathrm{~h}$ after therapy start: $\triangle$ MPAP -14.0 versus $\mathbf{- 8 . 0} \mathbf{~ m m H g} ; 23.5 \mathrm{~h}$ after therapy start). After therapy start, mean systemic arterial pressure (MAP) was not significantly different between the groups (end-point median: MAP ADM 70 (61/74) versus control 72 (54/81) mmHg). Endothelin-1, a potent pulmonary vasoconstrictor, is regulated by ADM via cAMP. Twenty two hours after inhalation of aerosolised ADM, endothelin-1 mRNA in lung tissue and endothelin-1 protein expression in pulmonary arteries was reduced compared with controls (median semi-quantitative immunhistochemical score: ADM 0.21, control 0.76).

Aerosolised adrenomedullin significantly reduced mean pulmonary artery pressure independently of arterial oxygen tension.

Eur Respir J 2004; 24: 615-623.
*Klinik für Kinder und Jugendliche und ${ }^{\#}$ Pathologisches Institut, der FriedrichAlexander-Universität, Erlangen-Nürnberg, Germany.

Correspondence: M.A. Kandler, Klinik für Kinder und Jugendliche, Loschgestrasse 15, D-91054 Erlangen, Germany.

Fax: 4991318535867

E-mail: michael.kandler@web.de

Keywords: Acute respiratory distress syndrome, adrenomedullin, aerosol, endothelin-1, pulmonary hypertension

Received: February 122003

Accepted after revision: May 282004

"Both authors contributed equally to this work.

Supported by a grant from the IZKF (center for interdisciplinary clinical research), University Erlangen-Nürnberg, German Ministry for Education and Research, No. 01 KS 0002, Project C11.
Pulmonary hypertension is often associated with an imbalance of vasoconstrictor and vasodilator peptides [1]. Endothelin-1 (ET-1) is the most potent constrictor and has been implicated in the pathogenesis of pulmonary hypertension [2]. Adrenomedullin (ADM), which consists of 52 amino acids, is actively produced and secreted by various cell types, particularly the vascular endothelial and smooth muscle cells [3], and has potent vasodilator properties. Transgenic mice overexpressing ADM in their vasculature have been shown to be resistant to lipopolysaccharide (LPS)induced shock. LPS caused smaller drops in blood pressure and less severe organ damage than in the wild-type, despite lower basal blood pressure [4]. Moreover, ADM overexpression reduced reperfusion injury and superoxide production [5]. $\mathrm{ADM}^{-/-}$knock-out mice showed lethal cardiovascular pathology e.g. extreme hydrops foetalis [6], mice with $\mathrm{ADM}^{+/-}$ mutation exhibited elevated blood pressures with diminished nitric oxide production and increased oxidative stress [7, 8], suggesting a crucial role for ADM in the regulation of the cardiovascular system, particularly endothelial cell function. ADM plays an important role in vascular morphogenesis and the regulation of blood pressure by stimulating nitric oxide production [7].

Intravenous infusion of ADM in patients with pulmonary hypertension significantly reduced pulmonary vascular

For editorial comments see page 518. resistance. However, systemic vascular resistance was simultaneously decreased [9]. Similar effects were seen with the application of ADM to the pulmonary artery [10]. To increase the pulmonary selectivity of ADM-induced vasodilation, the current authors examined the effect of inhaled ADM on pulmonary artery pressure and systemic blood pressure, investigating interval doses $5.0-100 \mathrm{ng} \cdot \mathrm{kg}^{-1} \cdot \mathrm{min}^{-1}$. In this study, application of aerosolised ADM did not lead to a reduction of systemic arterial pressure and the reduction of pulmonary artery pressure by aerosolised ADM did not subside within $3 \mathrm{~h}$ after the discontinuation of ADM inhalation [11]. Moreover, post mortem analysis of lung tissue showed a reduction of interleukin (IL)-1 $\beta$ and transforming growth factor- $\beta$ gene expression and IL-1 $\beta$ protein concentration [12]. Since a significant improvement of oxygenation was seen after aerosolised ADM, the proportional contribution of oxygenation to the pulmonary vasodilator effect of ADM could not be defined. Therefore, in the present study, animals were kept at constant arterial oxygen tension $\left(\mathrm{Pa}, \mathrm{O}_{2}\right)$ after the inhalation of ADM $\left(50 \mathrm{ng} \cdot \mathrm{kg}^{-1} \cdot \mathrm{min}^{-1}\right)$ in both the ADM and control groups.

Since ADM increases intracellular cyclic AMP concentration [13, 14], which is itself a vasorelaxant [15], but also suppresses ET-1 synthesis [16], the current study assessed ET1 mRNA gene and protein expression in lung tissue.

The first objective of the present study was to examine whether short-term inhalation of ADM for $2 \mathrm{~h}$ would lead to 
a sustained reduction of pulmonary artery pressure for $24 \mathrm{~h}$. The second objective was to investigate whether the effect of ADM on pulmonary vasodilation is maintained when constant $\mathrm{Pa}, \mathrm{O}_{2}$ and constant carbon dioxide arterial tension $\left(\mathrm{Pa}, \mathrm{CO}_{2}\right)$ are provided.

\section{Material and methods}

\section{Study animals}

The study was approved by the Animal Care Committee of the University of Erlangen and the government of Mittelfranken, Germany, and performed according to the European community guidelines for the use of experimental animals.

Twelve piglets with a body weight of $3.3-4.1 \mathrm{~kg}$ were included in the study. After a venous catheter had been placed into an ear vein, anaesthesia was induced with midazolam $\left(1 \mathrm{mg} \cdot \mathrm{kg}^{-1}\right)$, fentanyl $\left(2.5 \mu \mathrm{g} \cdot \mathrm{kg}^{-1}\right)$ and ketamine $\left(5 \mathrm{mg} \cdot \mathrm{kg}^{-1}\right)$, followed by continuous infusion of midazolam $\left(1.5 \mathrm{mg} \cdot \mathrm{kg}^{-1} \cdot \mathrm{h}^{-1}\right)$, fentanyl $\left(0.01 \mathrm{mg} \cdot \mathrm{kg}^{-1} \cdot \mathrm{h}^{-1}\right)$ and ketamine $\left(15 \mathrm{mg} \cdot \mathrm{kg}^{-1} \cdot \mathrm{h}^{-1}\right)$, After tracheotomy, paralysis was induced with vecuronium $0.2 \mathrm{mg} \cdot \mathrm{kg}^{-1}$ i.v. and maintained with vecuronium $0.2 \mathrm{mg} \cdot \mathrm{kg}^{-1} \cdot \mathrm{h}^{-1}$. A central venous catheter $(4.5 \mathrm{~F}$; Cook $\mathbb{R}$, Mönchengladbach, Germany) was placed into the right jugular vein and a

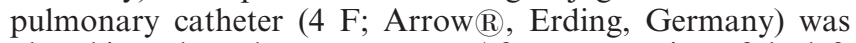
placed into the pulmonary artery. After preparation of the left femoral artery, an arterial catheter $(20 \mathrm{G}$; Arrow $\mathbb{R})$ and a sensor for online blood gas monitoring (Paratrend 7®; Philips $\mathbb{R}$, Böblingen, Germany) were inserted for online registration of blood gases. The piglets received a transcutaneous urinary catheter (Cystofix minipäd $\mathbb{R}$; Braun, Melsungen, Germany). Dynamic compliance and resistance were recorded with a hot wire anemometer (MIM $\mathbb{R}) \mathrm{GmbH}$, Krugzell, Germany), computed with the neonatal respiration

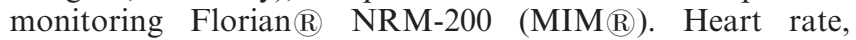
central venous, pulmonary artery and arterial pressure were continuously recorded (CMS 2001; Philips $\mathbb{R}$ ). Cardiac index (CI) was measured by thermodilution method before lavage and at the end of the observation period. Systemic vascular resistance index (SVRI) was computed as follows:

$$
\mathrm{SVRI}=79.9 \times(\mathrm{MAPCVP}) / \mathrm{CI}\left(\mathrm{dyn} \cdot \mathrm{s}^{1} \cdot \mathrm{cm}^{5} \cdot \mathrm{m}^{2}\right)
$$

Where MAP is mean arterial pressure and CVP is central venous pressure. Pulmonary vascular resistance index (PVRI) was computed as follows:

$$
\text { PVRI }=79.9 \times(\text { MPAPPCWP }) / C I\left(\text { dyn } \cdot \mathrm{s}^{1} \cdot \mathrm{cm}^{5} \cdot \mathrm{m}^{2}\right)
$$

Where MPAP is mean pulmonary arterial pressure and PCWP is pulmonary capillary wedge pressure. Arterial blood gas analysis was performed at $30 \mathrm{~min}$ intervals (ABL 330, Radiometer, Copenhagen, Denmark). Intermittent mandatory ventilation was performed with a neonatal respirator (Infant Star 950; Mallinckrodt ${ }^{\mathrm{TM}}$, Hennef, Germany). During instrumentation, induction of lung injury and ADM inhalation, breath rate was 50 breaths $\cdot \mathrm{min}^{-1}$, peak inspiratory pressure $32 \mathrm{~cm} \mathrm{H}_{2} \mathrm{O}$, positive end expiratory pressure $8 \mathrm{~cm}$ $\mathrm{H}_{2} \mathrm{O}$ and the inspiratory fractional oxygen concentration $\left(F \mathrm{I}, \mathrm{O}_{2}\right)$ 1.0. Respiratory gas was humidified and the temperature was adjusted to $39^{\circ} \mathrm{C}(\mathrm{MR} 700$; Fischer \& Paykel $\AA$, Welzheim, Germany). During instrumentation and for the duration of the experiment, animals were in supine position. Lung injury with pulmonary hypertension was induced by surfactant-depletion (repeated saline lung lavage). $\mathrm{NaCl} 0.9 \%$ $\left(30 \mathrm{~mL} \cdot \mathrm{kg}^{-1} ; 39^{\circ} \mathrm{C}\right)$ was instilled into the endotracheal tube, reaching the left and right side of the lung depending on the position of the animal (alternating left and right) [17]. Piglets were suctioned after each lavage. When the lung injury was considered stable, defined as $\mathrm{Pa}, \mathrm{O}_{2}$ remaining consistently $<9.3 \mathrm{kPa}$ for $60 \mathrm{~min}$, the piglets were included in the study. If inclusion criteria failed, repeated lung lavages were performed until the criteria were met.

\section{Methods}

After attaining inclusion criteria, the animals were randomly assigned to two different therapy groups (ADM and control). In all animals, respiratory support was maintained constant at identical respiratory settings during aerosol treatment. ADM (50 ng. kg ${ }^{-1} \mathrm{~min}^{-1}$, Bachem $\AA$, Heidelberg, Germany) was aerosolised with a jet aerosol device (AerProbe $\mathbb{R}$; Trudell $\mathbb{R}$, London, Canada) in saline solution $\left(4 \mathrm{~mL} \cdot \mathrm{h}^{-1}\right)$ over $2 \mathrm{~h}$. Piglets in the control group received aerosolised saline solution at equal volume. After the aerosol treatment, $F \mathrm{I}, \mathrm{O}_{2}$ and respiratory rate were continuously adjusted to keep $\mathrm{Pa}, \mathrm{O}_{2}$ and $\mathrm{Pa}, \mathrm{CO}_{2}$ within normal ranges for $22 \mathrm{~h}\left(\mathrm{~Pa}, \mathrm{O}_{2} 1.3-1.9 \mathrm{kPa}\right.$ and $\left.\mathrm{Pa}_{2} \mathrm{CO}_{2} 0.7-0.8 \mathrm{kPa}\right)$ to avoid oxygen induced vasodilation or $\mathrm{CO}_{2}$ induced vasoconstriction. After this observation period $(24 \mathrm{~h}$ after the establishment of lung injury), the animals were sacrificed by i.v. injection of $50 \mathrm{mg} \cdot \mathrm{kg}^{-1}$ methohexital and $20 \mathrm{~mL}$ potassium chloride $7.46 \%$. Lungs and heart were removed together. Tissue samples were taken from the right lung. mRNA extraction and reverse transcription was performed with guanidine-thiocyanate acid phenol (RNAzol; WAK Chemie $\mathbb{R}$, Medical GmbH, Bad Homburg, Germany). RNA $(1 \mathrm{~mL})$ was reverse transcribed in a volume of $20 \mu \mathrm{L}$ at $39^{\circ} \mathrm{C}$ for $60 \mathrm{~min}$ (all chemicals were obtained from

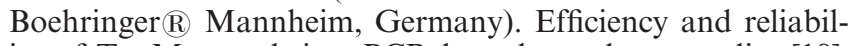
ity of TaqMan real time PCR have been shown earlier [18]. The use of TaqMan real time PCR in this animal model was published recently $[11,12]$. mRNA expression of ET-1 and IL-1 $\beta$ mRNA was normalised to hypoxanthine-guaninephosphoribosyl-transferase (HPRT) as a housekeeping gene. Primers and TaqMan probes were elected for the porcine model (table 1).

For immunohistology, $3 \mu \mathrm{m}$ paraffin sections were cut, dewaxed and incubated in $3 \% \mathrm{H}_{2} \mathrm{O}_{2}$ (20 min, room temperature) and subsequently with pronase (10 min, room temperature). Staining was then performed using an unconjugated ET-1 antibody (polyclonal rabbit; BioTrend Co., Cologne, Germany, 1:300, $1 \mathrm{~h}$ at $37^{\circ} \mathrm{C}$ ) and a second antibody (goat antirabbit, Vektor via Alexis Deutschland Co. Grünberg, Germany, 1:200, $30 \mathrm{~min}$, room temperature). The samples were then rinsed in Tris-buffered saline (pH 7.6) and submitted to the avidin-biotin system with tyramid enhancement (TSA-Biotin System; NEN Life Science, Cologne, Germany). Each incubation step was followed by a thorough

Table 1.-Primers and TaqMan probes

Endothelin-1

Forward 5' - CTCCTGCTCTTCCCTGATGG -3'

Reverse 5' - TGGCACACTGGCATCTATCC -3'

TaqMan probe $5^{\prime}$ (FAM)- TTCTGCCACCTGGACATCATTTGGG -(TAMRA) $3^{\prime}$

Interleukin-1 $\beta$

Forward 5' GGTTTCTGAAGCAGCCATGG -3'

Reverse 5' GATTTGCAGCTGGATGCTCC -3'

TaqMan probe $5^{\prime}$ (FAM)- AAAGAGATGAAGTGCTGCACCCAAAACCTG -(TAMRA) 3'

Hypoxanthine-guanine-phosphoribosyl-transferase

Forward 5'- CGGCTCCGTTATGGCG -3'

Reverse 5'- GGTCATAACCTGGTTCGTCATCA -3'

TaqMan probe 5'(FAM)- CGCAGCCCCAGCGTCGTGATTA-(TAMRA)3' 


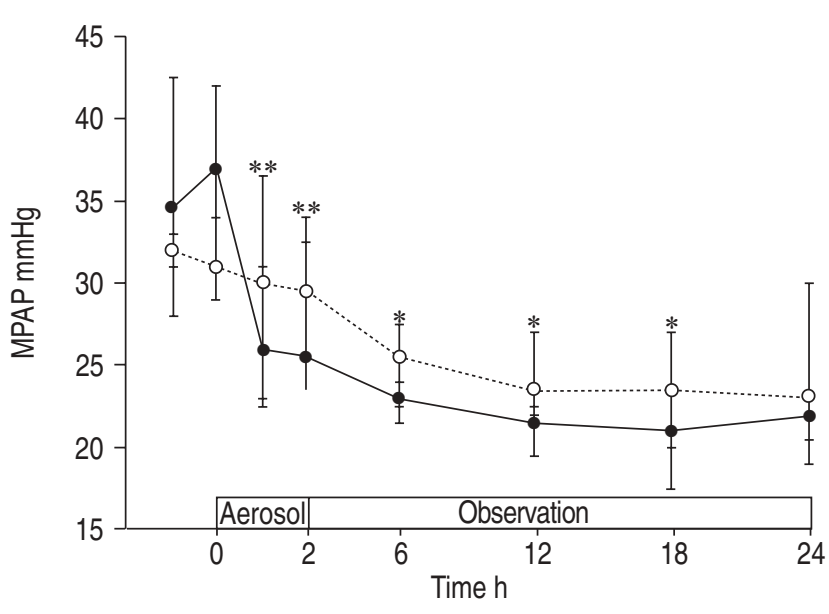

Fig. 1.- Mean pulmonary arterial pressure (MPAP) obtained after induction of lung injury, at start of treatment (T0), during therapy with aerosolised adrenomedullin (ADM; - ) and with normal saline (control group; $\bigcirc$ ) and during the post-treatment observation time in surfactant-depleted neonatal piglets. Data are presented as median \pm 25 th $/ 75$ th percentile. *: $\mathrm{p}<0.05 ; * *: \mathrm{p}<0.01$ MPAP reduction from baseline (T0), ADM versus control.

double rinse in Tris-buffered saline. AEC (Dako GmbH, Hamburg, Germany) served as a chromogen. Subsequently, sections were counterstained with Mayers haemalum (Merck Co., Darmstadt, Germany) and examined by light microscopy. Negative controls were performed by omitting the
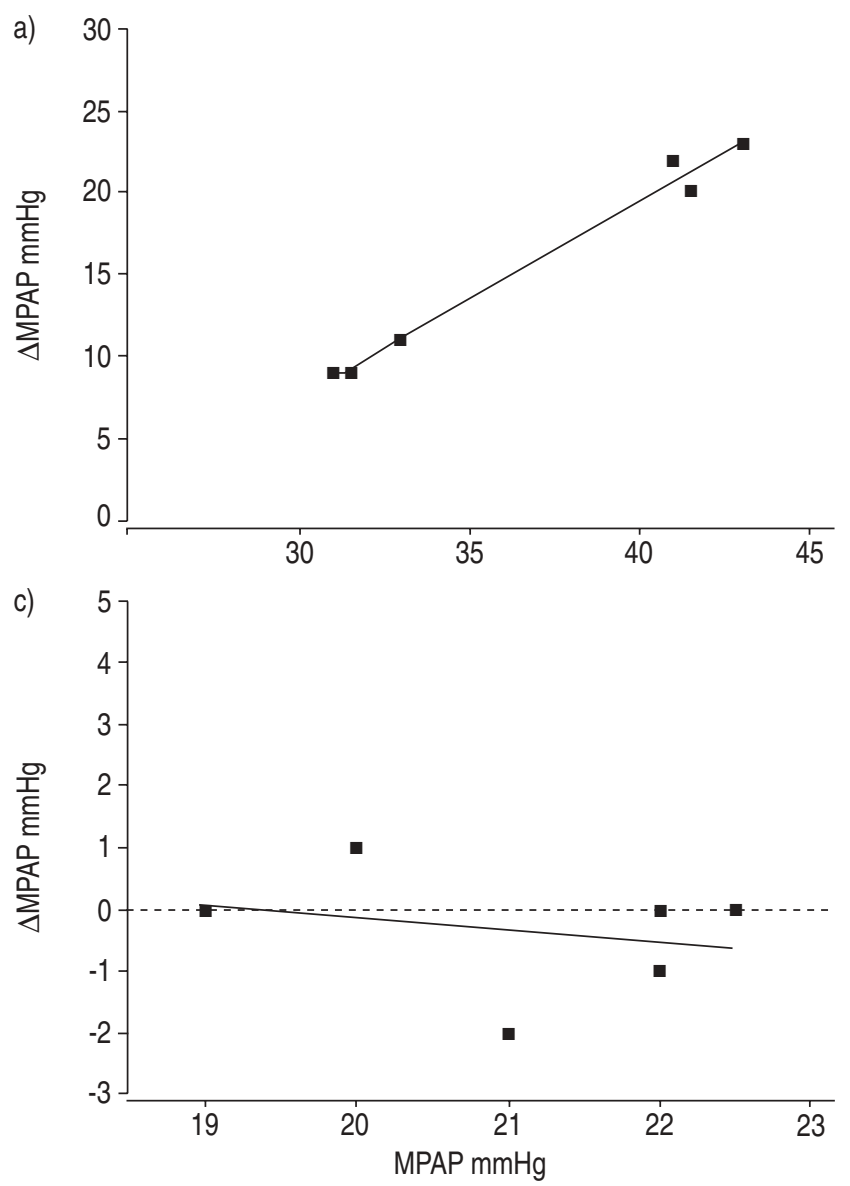

primary antibody. Staining of all sections was performed in the same run to reduce inter-run variations in staining intensity. Endothelial ET-1 protein expression was evaluated at high magnification in 3-21 pulmonary arteries per animal (mean $8.23 \pm 4.15$ ) using a semi-quantitative scoring system ( $0=$ no, $1=$ mild, $2=$ moderate, $3=$ strong ET-1 expression).

\section{Data analysis}

The data was recorded before and after the induction of lung injury (baseline; 0), during therapy and during the posttreatment observation time. A p-value of $<0.05$ was considered significant. Values are expressed as median (25th percentile/75th percentile). The Mann-Whitney U-test was used for comparison between groups.

\section{Results}

\section{Mean pulmonary artery pressure}

Induction of lung injury by bronchoalveolar lavage increased MPAP from 15.5 (15.0/17.0) to $37.0(31.0 / 42.0)$ $\mathrm{mmHg}$ (median $(25 \mathrm{P} / 75 \mathrm{P})$ ) in the ADM group and from 17.0 $(14.5 / 20.5)$ to $31.0(29.0 / 34.0) \mathrm{mmHg}$ in the control group. Values were not significantly different between the groups before treatment. Aerosolised ADM reduced MPAP significantly compared with the control group (fig. 1 and 2). In addition, the decline of MPAP was significantly faster in the b)

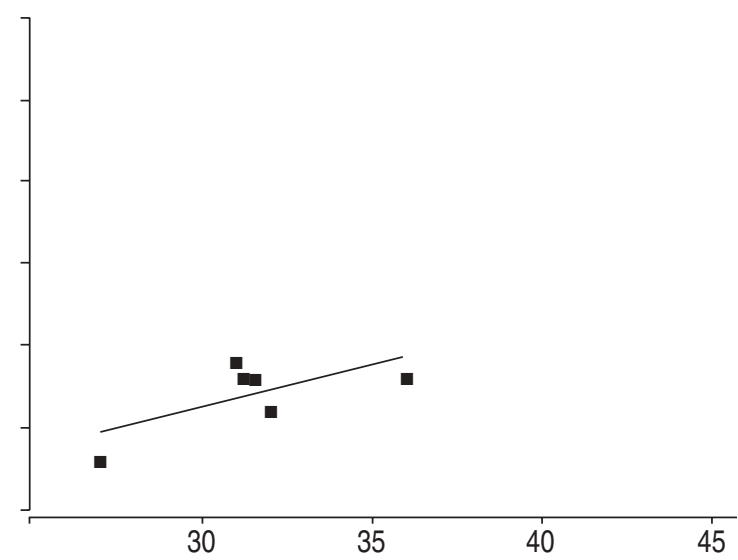

d)

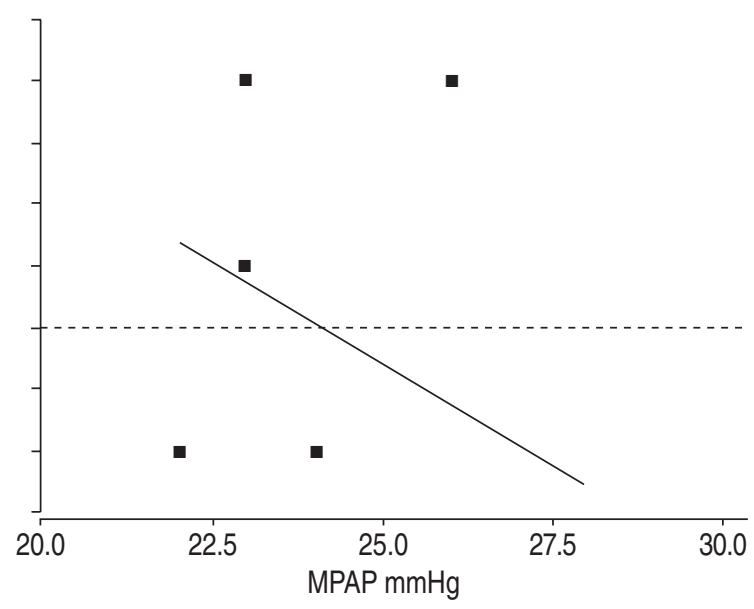

Fig. 2. - Linear correlation of change in mean pulmonary arterial pressure (AMPAP) versus MPAP during the first $12 \mathrm{~h}$ in a) adrenomedullin $(\mathrm{ADM})$ and $\mathrm{b})$ control groups and during the second $12 \mathrm{~h}$ in c) ADM and d) control groups. 
ADM than in the control group. The reduction in MPAP continued until $10 \mathrm{~h}$ after ADM aerosol treatment. Reduction in MPAP was significantly different from control up to $23.5 \mathrm{~h}$ after the start of the intervention.

\section{Mean arterial pressure}

During ADM aerosol inhalation and in the following $22 \mathrm{~h}$ there was no significant difference in MAP between the ADM and the control groups (fig. 3). However, there was a significant decrease in MAP in the ADM group, which was not found in the control group (table 2).

\section{Arterial oxygen and carbon dioxide tension}

There were no differences in $\mathrm{Pa}, \mathrm{O}_{2}$ and $\mathrm{Pa}, \mathrm{CO}_{2}$ between the ADM and control groups during the observation period (fig. 4 and 5) due to adaptation of respirator settings. The difference in $\mathrm{Pa}, \mathrm{O}_{2} / \mathrm{FI}, \mathrm{O}_{2}$ (Horowitz index) during $\mathrm{ADM}$ inhalation did not reach significance (fig. 6).

\section{Mixed venous oxygen tension}

During ADM aerosol application, mixed venous oxygen tension $\left(P_{\mathrm{v}}, \mathrm{O}_{2}\right)$ rose significantly $(\mathrm{p}<0.01)$ compared with the control group $\left(\Delta P_{\mathrm{v}}, \mathrm{O}_{2} \mathrm{p}<0.05\right.$ at 1,12 , and $18 \mathrm{~h}, \mathrm{p}<0.01$ at 2 , 6 , and $24 \mathrm{~h}$ after the start of treatment). $P_{\mathrm{v}}, \mathrm{O}_{2}$ was significantly higher during ADM aerosol inhalation and in the observation period than in controls after treatment start (table 2).

\section{Respiratory resistance and dynamic compliance}

There were no differences in respiratory resistance or dynamic compliance between the ADM and control group during treatment or during the observation period (table 2).

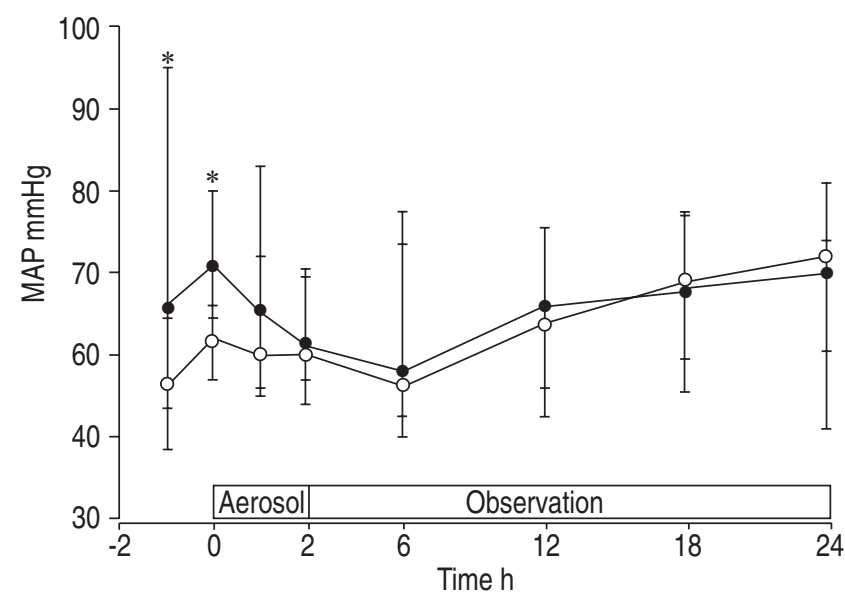

Fig. 3.-Mean arterial pressure (MAP) obtained after induction of lung injury, at the start of treatment (T0), during therapy with aerosolised adrenomedullin (ADM; O) and with normal saline (control group; $\bigcirc$ ) and during the post-treatment observation time in surfactant-depleted neonatal piglets. Data are presented as median \pm 25 th $/ 75$ th percentile. *: $\mathrm{p}<0.05$ MAP reduction from baseline (T0), ADM versus control.
Cardiac index, pulmonary capillary wedge pressure, vascular resistance indices

There were no differences in CI (ADM $0.72(0.63 / 0.82)$, control $0.73(0.58 / 1.01) \mathrm{L} \cdot \mathrm{min}^{-1} \cdot \mathrm{m}^{-2}$ ), PCWP (ADM 7.63 (6.5/10.0), control 8.0 (3.5/8.0) $\mathrm{mmHg}$ ), SVRI (ADM 7201 $(6121 / 8356)$, control $\left.6410(6024 / 9005) \mathrm{dyn} \cdot \mathrm{s}^{-1} \cdot \mathrm{cm}^{-5} \cdot \mathrm{m}^{-2}\right)$ or PVRI (ADM 1712 (1030/2261), control 2014 (1344/2338) dyn $\left.\cdot \mathrm{s}^{-1} \cdot \mathrm{cm}^{-5} \cdot \mathrm{m}^{-2}\right)$ between the groups $24 \mathrm{~h}$ after treatment with aerosolised ADM.

\section{IL-1 $\beta$ gene expression}

IL-1 $\beta /$ HPRT mRNA expression in lung tissue $22 \mathrm{~h}$ after inhalation of aerosolised ADM was 16.6 (8.8/36.5) relative units (RU) (median (25th percentile/75th percentile)) for the ADM group and $23.5(14.2 / 49.4)$ RU for the control group $(\mathrm{p}=0.07)$.

\section{Endothelin-1 gene expression}

ET-1/HPRT mRNA expression in lung tissue $22 \mathrm{~h}$ after inhalation of aerosolised ADM was reduced compared with controls (ADM: 23.5 \pm 1.94 RU (mean \pm SEM), control: 36.1 \pm 4.42 RU, p<0.05 (fig. 7), ADM: 21.1 (14.4/28.5) RU (median (25th percentile/75th percentile)), control: 27.5 (14.3/ 49.2) $\mathrm{RU}, \mathrm{p}=0.09)$.

\section{Endothelin-1 immunhistology in pulmonary arteries}

ET-1 protein expression was significantly reduced in endothelial cells in pulmonary arteries of ADM treated animals compared with controls. Semi-quantitative ET-1 score was $0.21(0.03 / 0.28)$ in ADM treated and $0.76(0.50 /$ 1.21 ) in control animals, $\mathrm{p}<0.01$. In the arterial media, there was hardly any ET-1 protein expression (fig. 8).

\section{Discussion}

Pulmonary hypertension is a typical feature of acute respiratory distress syndrome (ARDS) and is caused mainly by pulmonary vasoconstriction due to hypoxia and the release of vasoconstrictive inflammatory mediators. ARDS associated with pulmonary hypertension is a typical constellation encountered in a clinical setting, and is associated with high mortality. Since proning of ARDS patients may improve ventilation and oxygenation [19, 20], animals in this study were kept in a supine position to minimise uncontrolled effects.

The beneficial role of ADM with regard to cardiovascular protection has previously been intensively studied [5, 8, 9, 21]. In the present study, a $2 \mathrm{~h}$ period of ADM inhalation significantly reduced pulmonary artery blood pressure. The attenuation was twice as high as in the control group. In contrast to experiments using inhaled nitric oxide or iloprost, the reduction of pulmonary artery pressure persisted for hours after the withdrawal of ADM. To the authors' knowledge, none of the standard inhalative therapies for pulmonary hypertension, such as iloprost or nitric oxide, shows a comparable long-term effect [22, 23]. Therefore, treatment with aerosolised ADM may be an option to reduce pulmonary arterial pressure persistently. In contrast, systemic administration of ADM provides only a short-term reduction of pulmonary artery resistance, which subsides a few minutes after ADM 
Table 2. - Delta mean pulmonary arterial pressure ( $\triangle \mathrm{MPAP})$, mean arterial pressure (MAP), arterial oxygen tension $\left(P a, \mathrm{O}_{2}\right)$, arterial carbon dioxide tension $\left(\mathrm{Pa}_{\mathrm{a}} \mathrm{CO}_{2}\right)$, mixed venous oxygen tension $\left(\mathrm{Pv}_{\mathrm{v}} \mathrm{O}_{2}\right)$, Horowitz index $\left(\mathrm{Pa}, \mathrm{O}_{2} / \mathrm{Fl}_{1}, \mathrm{O}_{2}\right)$, dynamic compliance, respiratory resistance, central venous pressure (CVP) and heart rate in adrenomedullin (ADM) and control groups

\begin{tabular}{|c|c|c|c|c|c|c|}
\hline & \multirow[t]{2}{*}{ Baseline } & \multirow{2}{*}{$\begin{array}{c}2 \mathrm{~h} \\
\text { treatment }\end{array}$} & \multicolumn{4}{|c|}{ Time after baseline $h$} \\
\hline & & & 6 & 12 & 18 & 24 \\
\hline \multicolumn{7}{|c|}{$\triangle \mathrm{MPAP} \mathrm{mmHg}$} \\
\hline ADM & & $-8.5^{*}$ & $-15.0^{*}$ & $-15.5^{* *}$ & $-13.5^{*}$ & -13.5 \\
\hline$\%$ & & -23.1 & -40.1 & -41.1 & -36.5 & -37.1 \\
\hline $25 \mathrm{P}$ & & -14.0 & -19.0 & -22.5 & -24.5 & -23.0 \\
\hline $75 \mathrm{P}$ & & -4.5 & -7.5 & -9.0 & -10.0 & -8.5 \\
\hline Control & & -2.0 & -6.5 & -8.0 & -8.0 & -8.0 \\
\hline$\%$ & & -6.9 & -20.7 & -24.0 & -25.4 & -25.8 \\
\hline $25 \mathrm{P}$ & & -6.0 & -10.5 & -8.5 & -11.0 & -8.5 \\
\hline $75 \mathrm{P}$ & & -0.5 & -1.5 & -4.5 & -4.5 & -4.0 \\
\hline \multicolumn{7}{|c|}{$\mathrm{Pa}, \mathrm{O}_{2} \mathrm{mmHg}$} \\
\hline ADM & 53 & 125 & 112 & 112 & 106 & 97 \\
\hline $25 \mathrm{P}$ & 48 & 74 & 112 & 104 & 99 & 75 \\
\hline $75 \mathrm{P}$ & 60 & 147 & 136 & 123 & 134 & 123 \\
\hline Control & 56 & 92 & 113 & 119 & 116 & 107 \\
\hline $25 \mathrm{P}$ & 44 & 59 & 87 & 101 & 98 & 84 \\
\hline $75 \mathrm{P}$ & 64 & 116 & 125 & 130 & 124 & 129 \\
\hline \multicolumn{7}{|c|}{$\Delta \mathrm{MAP} \mathrm{mmHg}$} \\
\hline ADM & & $-8.5^{*}$ & -7.5 & -9.5 & $-8.0^{*}$ & -4.5 \\
\hline$\%$ & & -11.6 & -10.5 & -13.3 & -11.3 & -5.8 \\
\hline $25 \mathrm{P}$ & & -15.0 & -18.5 & -14.0 & -11.0 & -10.0 \\
\hline $75 \mathrm{P}$ & & -3.0 & -1.5 & 2.0 & 1.0 & 3.5 \\
\hline Control & & -1.0 & -2.0 & 5.0 & 7.5 & 11.5 \\
\hline$\%$ & & -1.7 & -3.5 & 7.9 & 12.1 & 18.7 \\
\hline $25 \mathrm{P}$ & & -4.0 & -10.5 & -6.0 & -2.0 & -8.0 \\
\hline $75 \mathrm{P}$ & & 5.0 & 8.0 & 11.5 & 15.5 & 19.0 \\
\hline \multicolumn{7}{|c|}{$\mathrm{Pa}_{\mathrm{a}, \mathrm{Co}_{2} \mathrm{mmHg}}$} \\
\hline ADM & 52.2 & 36.0 & 38.9 & 39.0 & 39.1 & 44.2 \\
\hline $25 \mathrm{P}$ & 39.3 & 34.8 & 35.3 & 36.2 & 38.3 & 38.1 \\
\hline $75 \mathrm{P}$ & 60.7 & 38.7 & 41.6 & 40.6 & 40.4 & 51.1 \\
\hline Control & 53.6 & 40.3 & 39.0 & 39.3 & 38.9 & 37.0 \\
\hline $25 \mathrm{P}$ & 49.2 & 36.4 & 35.4 & 32.0 & 35.7 & 34.9 \\
\hline $75 \mathrm{P}$ & 63.5 & 46.8 & 41.5 & 43.9 & 41.3 & 40.6 \\
\hline \multicolumn{7}{|c|}{$P_{\mathrm{V},}, \mathrm{O}_{2} \mathrm{mmHg}$} \\
\hline ADM & 35.7 & $43.1^{*}$ & $44.3^{* *}$ & 42.6 & $41.1 *$ & $40.4 * *$ \\
\hline $25 \mathrm{P}$ & 33.7 & 39.1 & 42.1 & 38.6 & 36.4 & 36.0 \\
\hline $75 \mathrm{P}$ & 38.0 & 46.3 & 47.2 & 46.3 & 47.2 & 45.0 \\
\hline Control & 34.9 & 34.8 & 35.7 & 33.1 & 34.0 & 32.6 \\
\hline $25 \mathrm{P}$ & 30.4 & 29.2 & 28.2 & 28.1 & 29.7 & 27.1 \\
\hline $75 \mathrm{P}$ & 39.8 & 38.3 & 39.6 & 43.9 & 39.2 & 36.2 \\
\hline \multicolumn{7}{|l|}{$P a, O_{2} / F I, O_{2}$} \\
\hline ADM & 53.4 & 168 & 210 & 222 & 144 & 130 \\
\hline $25 \mathrm{P}$ & 47.7 & 84.8 & 186 & 155 & 127 & 89.8 \\
\hline $75 \mathrm{P}$ & 59.9 & 217 & 441 & 256 & 226 & 208 \\
\hline Control & 56.3 & 92.7 & 206 & 211 & 206 & 183 \\
\hline $25 \mathrm{P}$ & 44.5 & 58.7 & 102 & 135 & 125 & 104 \\
\hline $75 \mathrm{P}$ & 64.4 & 209 & 258 & 266 & 272 & 258 \\
\hline \multicolumn{7}{|c|}{$\begin{array}{l}\text { Dynamic compliance } \\
\qquad \mathrm{mL} \cdot \mathrm{cm}^{-1} \mathrm{H}_{2} \mathrm{O} \cdot \mathrm{kg}^{-1}\end{array}$} \\
\hline ADM & 0.44 & 0.51 & 0.54 & 0.51 & 0.50 & 0.46 \\
\hline $25 \mathrm{P}$ & 0.40 & 0.42 & 0.48 & 0.46 & 0.46 & 0.39 \\
\hline $75 \mathrm{P}$ & 0.51 & 0.62 & 0.60 & 0.55 & 0.61 & 0.52 \\
\hline Control & 0.42 & 0.44 & 0.47 & 0.50 & 0.46 & 0.48 \\
\hline $25 \mathrm{P}$ & 0.35 & 0.38 & 0.40 & 0.42 & 0.37 & 0.38 \\
\hline $75 \mathrm{P}$ & 0.44 & 0.47 & 0.49 & 0.56 & 0.52 & 0.56 \\
\hline \multicolumn{7}{|c|}{ Resistance $\mathrm{cm} \mathrm{H}_{2} \mathrm{O} \cdot \mathrm{L}^{-1} \cdot \mathrm{s}^{-1}$} \\
\hline ADM & 121 & 138 & 142 & 115 & 112 & 114 \\
\hline $25 \mathrm{P}$ & 107 & 106 & 119 & 101 & 102 & 106 \\
\hline $75 \mathrm{P}$ & 127 & 164 & 148 & 119 & 126 & 137 \\
\hline Control & 125 & 118 & 120 & 105 & 117 & 123 \\
\hline $25 \mathrm{P}$ & 119 & 110 & 108 & 96 & 102 & 96 \\
\hline $75 \mathrm{P}$ & 127 & 153 & 150 & 139 & 154 & 159 \\
\hline \multicolumn{7}{|c|}{ CVP mmHg } \\
\hline ADM & 5.0 & 5.0 & 4.0 & 4.0 & 4.0 & 4.0 \\
\hline
\end{tabular}


Table 2.-(Continued)

\begin{tabular}{|c|c|c|c|c|c|c|}
\hline & \multirow[t]{2}{*}{ Baseline } & \multirow{2}{*}{$\begin{array}{l}2 \mathrm{~h} \\
\text { treatment }\end{array}$} & \multicolumn{4}{|c|}{ Time after baseline $\mathrm{h}$} \\
\hline & & & 6 & 12 & 18 & 24 \\
\hline $25 \mathrm{P}$ & 4.0 & 4.0 & 3.5 & 3.5 & 3.5 & 3.5 \\
\hline $75 \mathrm{P}$ & 5.5 & 7.5 & 7.0 & 4.5 & 4.5 & 6.5 \\
\hline Control & 4.0 & 4.0 & 5.0 & 3.0 & 4.0 & 3.0 \\
\hline $25 \mathrm{P}$ & 2.0 & 1.5 & 1.5 & 2.0 & 1.5 & 1.5 \\
\hline $75 \mathrm{P}$ & 9.0 & 6.0 & 6.5 & 4.0 & 4.0 & 4.5 \\
\hline \multicolumn{7}{|c|}{ Heart rate $\cdot \min ^{-1}$} \\
\hline ADM & 184 & 159 & 131 & 141 & 127 & 148 \\
\hline $25 \mathrm{P}$ & 119 & 125 & 113 & 114 & 120 & 108 \\
\hline $75 \mathrm{P}$ & 223 & 199 & 169 & 176 & 181 & 164 \\
\hline Control & 159 & 169 & 141 & 157 & 157 & 180 \\
\hline $25 \mathrm{P}$ & 136 & 136 & 120 & 131 & 130 & 128 \\
\hline $75 \mathrm{P}$ & 208 & 188 & 189 & 191 & 182 & 186 \\
\hline
\end{tabular}

Data are presented as median, per cent, 25 th percentile $(25 \mathrm{P})$ and 75 th percentile $(75 \mathrm{P}) .{ }^{*}: \mathrm{p}<0.05$; **: $\mathrm{p}<0.01 . \mathrm{kPa}=\mathrm{mmHg} \times 0.133$.

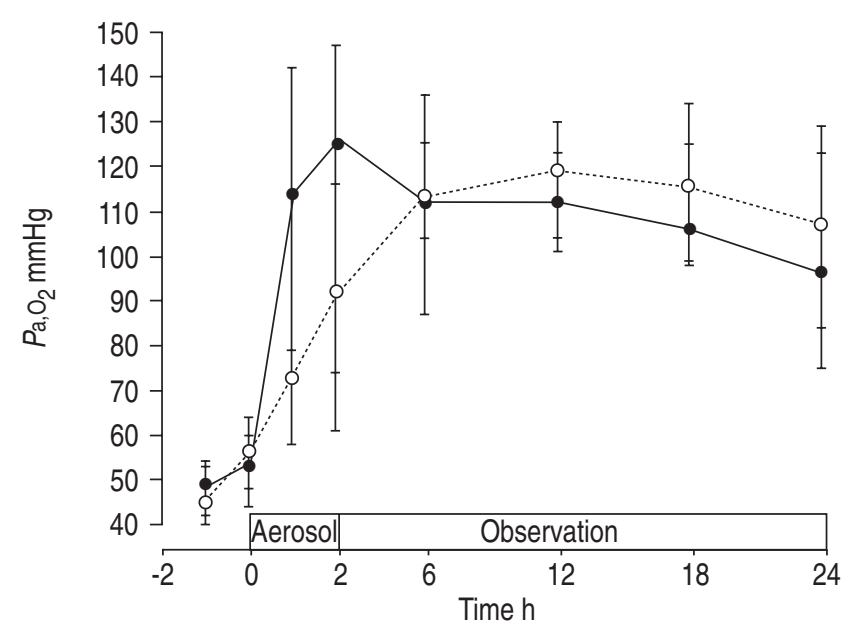

Fig. 4. - Arterial oxygen tension $\left(\mathrm{P}_{\mathrm{a}}, \mathrm{O}_{2}\right)$ obtained after induction of lung injury, at start of treatment (T0), during therapy with aerosolised adrenomedullin (৩) and with normal saline (control group; $\bigcirc$ ) and during the post-treatment observation time in surfactant-depleted neonatal piglets. Data are presented as median \pm 25 th $/ 75$ th percentile.

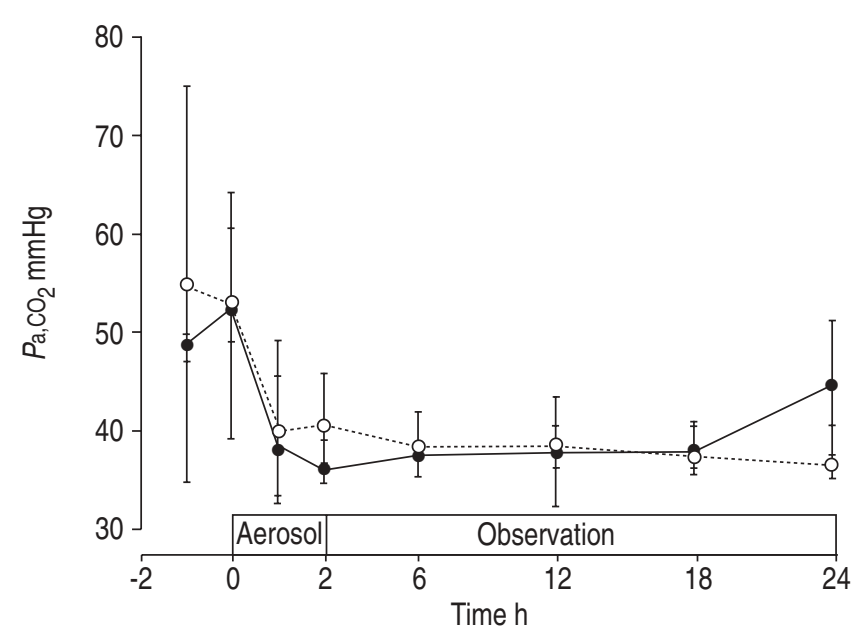

Fig. 5. - Arterial carbon dioxide $\left(\mathrm{Pa}_{\mathrm{a}} \mathrm{CO}_{2}\right)$ obtained after induction of lung injury, at start of treatment ( $\mathrm{T} 0)$, during therapy with aerosolised adrenomedullin (-) and with normal saline (control group; $\bigcirc$ ) and during the post-treatment observation time in surfactant depleted neonatal piglets. Data are presented as median \pm 25 th $/ 75$ th percentile.

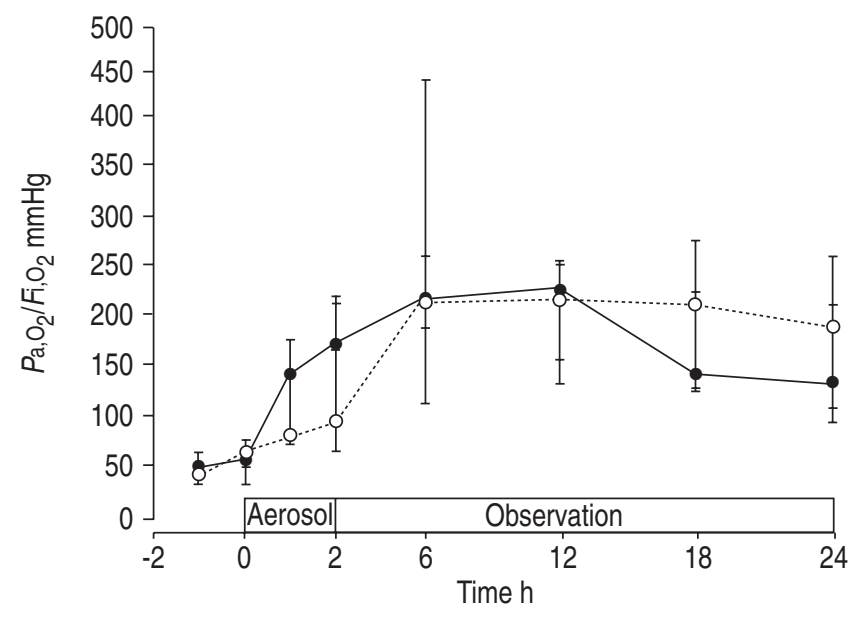

Fig. 6. - Arterial oxygen tension $\left(\mathrm{P}_{\mathrm{a}, \mathrm{O}_{2}}\right)$ /inspiratory oxygen fraction $\left(F \mathrm{I}, \mathrm{O}_{2}\right)$ (Horowitz index) obtained after induction of lung injury, at start of treatment (T0), during therapy with aerosolised adrenomedullin (๑) and with normal saline (control group; $\bigcirc$ ) and during the post-treatment observation time in surfactant-depleted neonatal piglets. Data are presented as median $\pm 25 \mathrm{th} / 75$ th percentile.

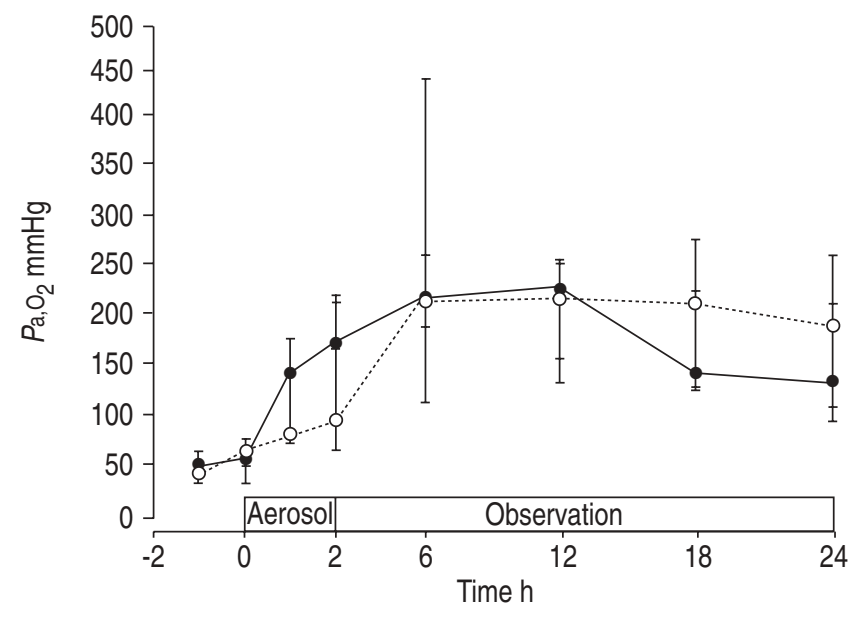

Fig. 7. - Endothelin-1/Hypoxanthine-guanine-phosphoribosyl-transferase (HPRT) mRNA expression in lung tissue of surfactant-depleted piglets post mortem, after therapy with aerosolised adrenomedullin (ADM) or with aerosolised normal saline (control group) during intermittent mandatory ventilation and an additional observation period of $22 \mathrm{~h}$. Data are presented as relative units, median $\pm 25 \mathrm{th} /$ 75th percentile. *: $\mathrm{p}<0.05$ ADM versus control. 

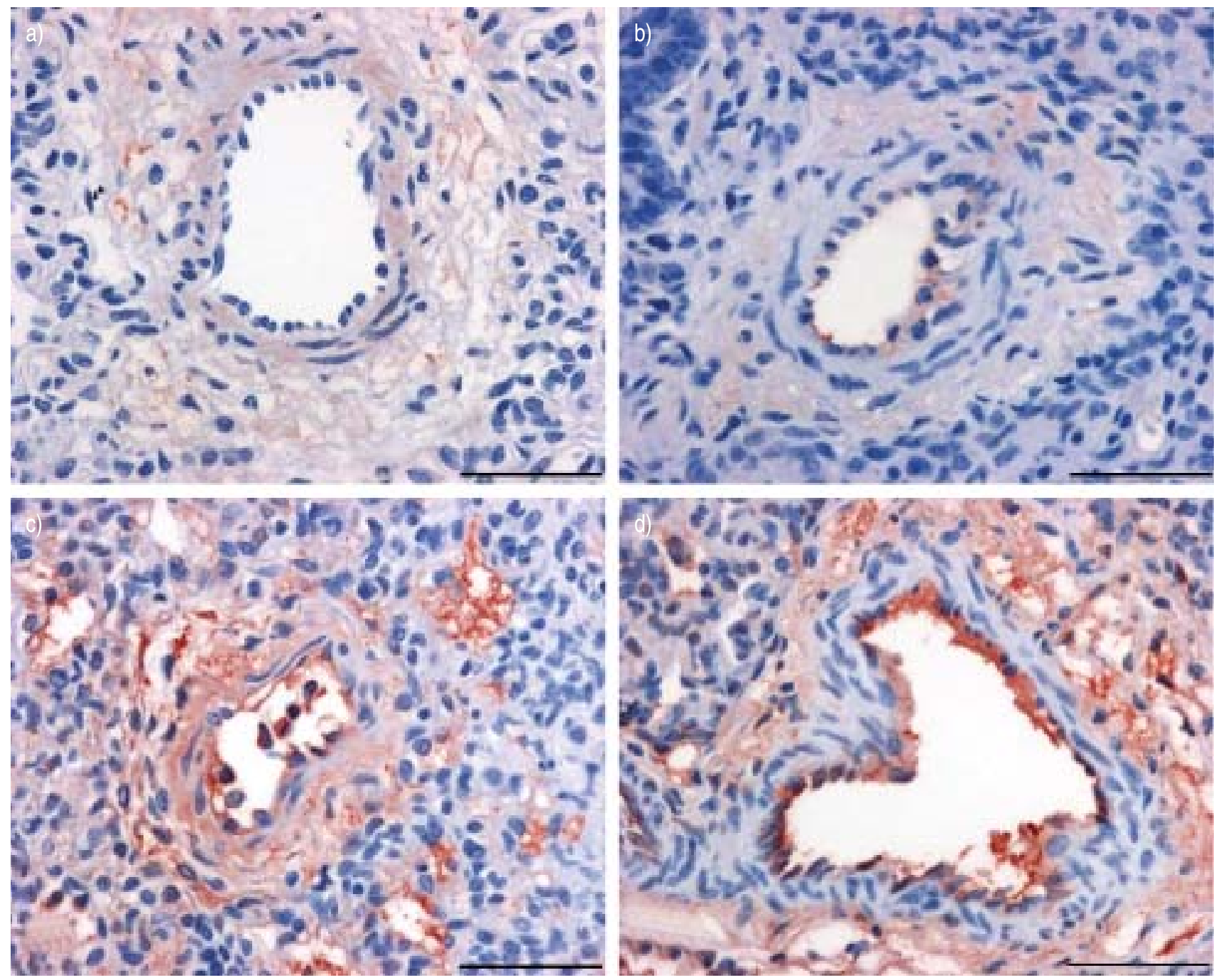

Fig. 8. - Endothelin-1 protein expression in pulmonary arteries of the anterior (a, c) and posterior (b, d) lower lobe of surfactant depleted piglets $22 \mathrm{~h}$ after a $2 \mathrm{~h}$ treatment period with aerosolised adrenomedullin $(\mathrm{a}, \mathrm{b})$ or with aerosolised normal saline (control) $(\mathrm{c}, \mathrm{d})$. Scale bar=50 $\mu \mathrm{m}$.

withdrawal [9] and induces a considerable reduction in systemic arterial blood pressure. In a previous study, the vasodilation by aerosolised ADM was selective for pulmonary vessels without lowering systemic blood pressure [11]. In the present study, the significant decrease in MAP compared with control may be due to the significantly higher MAP at therapy start in the ADM group or may be caused by differences in ADM aerosol dosing $\left(50 \mathrm{ng} \cdot \mathrm{kg}^{-1} \cdot \mathrm{min}^{-1}\right.$ continuously for $2 \mathrm{~h}$ compared with a 30 min interval therapy in the previous study). As the absolute MAP values in the ADM and control group were identical, this finding is not of great importance. The exact mechanism of ADM-induced pulmonary vasodilation has not yet been completely resolved. One known mechanism of ADM vasodilation is the activation of endothelial NO synthases [24], however, the ADM effect is not mediated exclusively via NO [25]. The authors have previously reported in a pilot study of surfactant-depleted piglets, that the inhibition of NO synthases with L-NAME did not alter the pulmonary vasodilative effect of aerosolised ADM [11, 26]. Other mechanisms may therefore be of predominant importance. As previously demonstrated, oxygenation is improved during and after therapy with aerosolised ADM [11]. As improved oxygenation may itself lead to pulmonary vasodilation, the proportional contribution of improved $\mathrm{Pa}, \mathrm{O}_{2}$ to pulmonary vasodilation could not be defined in the previous study. The authors therefore adjusted ventilator settings to maintain $\mathrm{Pa}, \mathrm{O}_{2}$ and $\mathrm{Pa}, \mathrm{CO}_{2}$ at constant physiological levels. This long-term model with identical $\mathrm{Pa}, \mathrm{O}_{2}$ in the $\mathrm{ADM}$ and control group now clearly demonstrates that the pulmonary vasodilative effect of aerosolised ADM is not mediated via oxygen. A bias due to different inspiratory oxygen concentrations between the groups in favour of the ADM group can be excluded, as inspiratory oxygen concentration was not higher in the ADM group. As there was no significant difference in $F \mathrm{I}, \mathrm{O}_{2}$ or $\mathrm{Pa}, \mathrm{O}_{2} / F \mathrm{I}, \mathrm{O}_{2}$ between the groups, the effect of ADM on oxygenation has to be regarded as marginal in this study. However, the improvement of $P_{\mathrm{v}}, \mathrm{O}_{2}$ may indicate augmented oxygen transport to peripheral tissue, but oxygen transport was not investigated in this study. Dynamic compliance and respiratory resistance did not change significantly during the experiment and a bronchodilator response to ADM must remain speculative. Reduced ET-1 gene expression in the ADM group as seen in the present long-term study and also in the previous pilot study [11] demonstrates a possible ADM effect via reduction of the vasoconstrictive functional ADM antagonist ET-1. The potential importance of this mechanism is demonstrated by reduced ET-1 protein expression in pulmonary arteries of the ADM-treated group.

Within the respiratory tract, ET-1 is a potent vasoconstrictor 
of pulmonary artery vessels and plays an important role in pulmonary hypertension. The reduction of ET-1 gene and protein expression following treatment with aerosolised ADM could be mediated by the suppressive effect of the ADM second messenger cAMP on ET-1 synthesis [13, 16]. Future studies on ET-1 antagonists may indicate whether this is the predominant mechanism. Reduction of ET-1 expression could contribute especially to the observed prolonged effect of aerosolised ADM on pulmonary artery pressure. cAMP is also a vasorelaxant and may contribute to the acute vasodilative effect of ADM. An acute vasodilative effect of $\mathrm{ADM}$ has been shown to be mediated, at least in part, by activation of nitric oxide synthases [27]. Alternatively, ADM peptide could accumulate in the alveolar space during inhalation, leading to a prolonged effect on the pulmonary vascular bed. As the biological half life of ADM is quite short (18 $\mathrm{min}$ ) [21], this mechanism is rather unlikely. In addition, it may be speculated that the mechanism of ADM action is via an increased activity of prostaglandins or is exerted by activation of calcitonin gene-related peptide receptor [10]. The ADM effect may be increased by previous hypoxia, which has been shown to upregulate ADM receptor function [28]. ADM effects on pulmonary vascular resistance could not be recorded in the current study, the considerable side-effects of CI measurement by thermodilution and registration of pulmonary capillary wedge pressure in piglets with severe ARDS allowed measurement of these parameters only before and after the experiment. Possible effects on pulmonary vascular resistance may, therefore, not have been detected. Reduction of IL-1 $\beta$ mRNA expression in lung tissue almost reached significance. The lack of definitive significance may be due to the small number of piglets enrolled and the considerably long observation period of $22 \mathrm{~h}$ after the end of ADM application. How and where ADM or its mediators (e.g. cAMP or NO) reach the pulmonary artery system via the bronchiolo-alveolar system has not yet been defined and cannot be defined by the data of the current study. The study is limited by the use of an ARDS model of pulmonary hypertension, since the vasodilative effect of aerosolised ADM may be restricted to the model investigated. The effects of aerosolised ADM on pulmonary hypertension should be re-evaluated using another animal model of pulmonary hypertension. A direct comparison with inhaled NO or iloprost would be additionally helpful.

In conclusion, aerosolised adrenomedullin significantly reduces the mean pulmonary artery pressure independently of the arterial oxygen tension. This effect may be partially mediated via reduction of endothelin-1. Aerosolised adrenomedullin could be a potential alternative therapy for pulmonary hypertension, since pulmonary vasodilators having an antiinflammatory potential and the capability to interact with the upregulated endothelin-1 system could be an innate way to normalise pulmonary vascular tension.

Acknowledgements. The authors would like to thank S. Gastiger, S. Mahfoud, J. Walther and M. Klewer for excellent technical assistance. They also gratefully acknowledge the support of the monitor system CMS 2001 from Philips $\AA$, Böblingen, Germany. Special thanks to W. Stöhr for statistical advice.

\section{References}

1. Keith IM. The role of endogenous lung neuropeptides in regulation of the pulmonary circulation. Physiol Res 2000; 49: $519-537$.
2. Giaid A, Yanagisawa M, Langleben D, et al. Expression of endothelin-1 in the lungs of patients with pulmonary hypertension. N Engl J Med 1993; 328: 1732-1739.

3. Sugo S, Minamino N, Shoji H, et al. Interleukin-1, tumour necrosis factor and lipopolysaccharide additively stimulate production of adrenomedullin in vascular smooth muscle cells. Biochem Biophys Res Commun 1995; 207: 25-32.

4. Shindo T, Kurihara H, Maemura K, et al. Hypotension and resistance to lipopolysaccharide-induced shock in transgenic mice overexpressing adrenomedullin in their vasculature. Circulation 2000; 101: 2309-2316.

5. Chao J, Kato K, Zhang JJ, et al. Human adrenomedullin gene delivery protects against cardiovascular remodeling and renal injury. Peptides 2001; 22: 1731-1737.

6. Caron KM, Smithies O. Extreme hydrops foetalis and cardiovascular abnormalities in mice lacking a functional Adrenomedullin gene. Proc Natl Acad Sci USA 2001; 98: 615-619.

7. Shindo $\mathrm{T}$, Kurihara $\mathrm{Y}$, Nishimatsu $\mathrm{H}$, et al. Vascular abnormalities and elevated blood pressure in mice lacking adrenomedullin gene. Circulation 2001; 104: 1964-1971.

8. Shimosawa T, Shibagaki Y, Ishibashi K, et al. Adrenomedullin, an endogenous peptide, counteracts cardiovascular damage. Circulation 2002; 105: 106-111.

9. Nagaya N, Nishikimi T, Uematsu M, et al. Haemodynamic and hormonal effects of adrenomedullin in patients with pulmonary hypertension. Heart 2000; 84: 653-658.

10. Takahashi Y, de Vroomen M, Gournay V, Roman C, Rudolph AM, Heymann MA. Mechanisms of adrenomedullin-induced increase of pulmonary blood flow in foetal sheep. Pediatr Res 1999; 45: 276-281.

11. Kandler MA, von der Hardt K, Mahfoud S, et al. Pilot intervention: aerosolized adrenomedullin reduces pulmonary hypertension. J Pharmacol Exp Ther 2003; 306: 1021-1026.

12. von der Hardt K, Kandler MA, Popp K, et al. Aerosolized adrenomedullin suppresses pulmonary transforming growth factor-betal and interleukin-1beta gene expression in vivo. Eur J Pharmacol 2002; 457: 71-76.

13. Ishizaka Y, Ishizaka Y, Tanaka M, et al. Adrenomedullin stimulates cyclic AMP formation in rat vascular smooth muscle cells. Biochem Biophys Res Commun 1994; 200: 642-646.

14. Shimekake Y, Nagata K, Ohta S, et al. Adrenomedullin stimulates two signal transduction pathways, cAMP accumulation and $\mathrm{Ca} 2+$ mobilization, in bovine aortic endothelial cells. J Biol Chem 1995; 270: 4412-4417.

15. Maurice DH, Haslam RJ. Nitroprusside enhances isoprenaline-induced increases in cAMP in rat aortic smooth muscle. Eur J Pharmacol 1990; 191: 471-475.

16. Magnusson A, Halldorsson H, Thorgeirsson G, Kjeld M. Endothelin secretion is regulated by cyclic AMP and phosphatase 2A in endothelial cells. J Cell Physiol 1994; 161: 429-434.

17. Kandler MA, von der Hardt K, Schoof E, Dotsch J, Rascher W. Persistent improvement of gas exchange and lung mechanics by aerosolized perfluorocarbon. Am J Respir Crit Care Med 2001; 164: 31-35.

18. Dötsch J, Nusken KD, Knerr I, Kirschbaum M, Repp R, Rascher W. Leptin and neuropeptide Y gene expression in human placenta: ontogeny and evidence for similarities to hypothalamic regulation. J Clin Endocrinol Metab 1999; 84: 2755-2758.

19. Lim CM, Koh Y, Chin JY, et al. Respiratory and haemodynamic effects of the prone position at two different levels of PEEP in a canine acute lung injury model. Eur Respir J 1999; 13: 163-168.

20. Pelosi P, Brazzi L, Gattinoni L. Prone position in acute respiratory distress syndrome. Eur Respir J 2002; 20: $1017-$ 1028.

21. Cockcroft JR, Noon JP, Gardner-Medwin J, Bennett T. Haemodynamic effects of adrenomedullin in human resistance and capacitance vessels. Br J Clin Pharmacol 1997; 44: 57-60. 
22. Demirakca S, Dotsch J, Knothe $\mathrm{C}$, et al. Inhaled nitric oxide in neonatal and paediatric acute respiratory distress syndrome: dose response, prolonged inhalation, and weaning. Crit Care Med 1996; 24: 1913-1919.

23. Olschewski H, Ghofrani HA, Schmehl T, et al. Inhaled iloprost to treat severe pulmonary hypertension. An uncontrolled trial. German PPH Study Group. Ann Intern Med 2000; 132: 435-443.

24. Hattori Y, Nakanishi N, Gross SS, Kasai K. Adrenomedullin augments nitric oxide and tetrahydrobioptein synthesis in cytokine-stimulated vascular smooth muscle cells. Cardiovasc Res 1999; 44: 207-214.

25. Kinnunen P, Piuhola J, Ruskoaho H, Szokodi I. AM reverses pressor response to ET-1 independently of NO in rat coronary circulation. Am J Physiol Heart Circ Physiol 2001; 281: 1178-1183.

26. von der Hardt K, Kandler MA, Schoof E, Dötsch J, Rascher W. Aerosolized adrenomedullin improves pulmonary hypertension and oxygenation and reduces fibrotic response. Eur J Pediatr 2002: 161.

27. Feng CJ, Kang B, Kaye AD, Kadowitz PJ, Nossaman BD. L-NAME modulates responses to adrenomedullin in the hindquarters vascular bed of the rat. Life Sci 1994; 55: 433-438.

28. Hänze J, Groneberg DA, Rose F, et al. Genomic organization and regulation of a human 7-helix transmembrane receptor which is expressed in pulmonary epithelial cells and induced in hypoxia. Biochem Biophys Res Commun 2002; 291: $1160-1165$. 